\title{
Apgar Scoring System in Brazil's Live Births Records: Differences between Home and Hospital Births
}

\section{Escala de Apgar nos registros de nascidos vivos do Brasil: discordância entre parto normal hospitalar e parto domiciliar}

\author{
Jordana de Faria Bessa10 Naieli Bonatto ${ }^{2}$ \\ ${ }^{1}$ Department of Gynecology, Clínica Humana, Guarulhos, SP, Brazil \\ 2 Department of Radiology and Oncology, Universidade de São Paulo, \\ São Paulo, SP, Brazil
}

Address for correspondence Jordana de Faria Bessa, MD, Departamento de Ginecologia, Clínica Humana, Rua Barão de Mauá, 155, 07012- 040, Guarulhos, SP, Brazil (e-mail: jordana.bessa@gmail.com).

Rev Bras Ginecol Obstet 2019;41:76-83.

\begin{abstract}
Keywords

- home birth

- normal birth

- apgar score

Resumo

Objective To promote informed choice for women and to compare home and hospital births in relation to the Apgar score.

Methods Mother's profile and Apgar score of naturally born infants (without forceps assistance) in Brazil between 2011 and 2015, in both settings-hospital or home-were collected from live birth records provided by the Informatics Department of the Unified Health System (DATASUS, in the Portuguese acronym). For the analysis, were included only data from low-risk deliveries, including gestational time between 37 and 41 weeks, singleton pregnancy, at least four visits of prenatal care, infants weighing between $2,500 \mathrm{~g}$, and $4,000 \mathrm{~g}$, mother age between 20-40 years old, and absence of congenital anomalies.

Results Home birth infants presented significantly higher risk of 0-5 Apgar scores, both in 1 minute $(6.4 \%$ versus $3 \%$, odds ratio $[\mathrm{OR}]=2.2$, confidence interval $[\mathrm{Cl}] \mathrm{IC} 2-2.4)$ and in 5 minutes ( $4.8 \%$ versus $0.4 \%, \mathrm{OR}=11.5, \mathrm{Cl} 10.5-12.7)$. Another finding is related to recovery estimates when from an initially bad 1 -minute $\operatorname{Apgar}(<6)$ to a subsequently better 5-minute Apgar ( $>6)$. In this scenario, home infants had poorer recovery, Apgar score was persistently $<6$ throughout the fifth minute in most cases (71\% versus $10.7 \%$, OR 20.4, Cl 17-24.6). Conclusion The results show worse Apgar scores for babies born at home, compared with those born at the hospital setting. This is a pioneer and preliminary study that brings attention concerning differences in Apgar score related to home versus hospital place of birth in Brazil.

Objetivo Promover a escolha informada para as mulheres, comparando os resultados de partos domiciliares e hospitalares em relação à escala de Apgar.

Métodos Foram coletadas as informações maternas e a pontuação Apgar de nascidos de parto normal (pela definição, sem auxílio de fórcipe) no Brasil, de 2011 a 2015, a partir de registros de nascidos vivos disponibilizados pela plataforma do Departamento de Informática do Sistema Único de Saúde (DATASUS). Para a análise, incluímos
\end{abstract}

(D)Jordana de Faria Bessa's ORCID is https://orcid.org/0000-00028056-6295.

received

May 28, 2018

accepted

August 31, 2018

published online

December 12, 2018
DOI https://doi.org/

10.1055/s-0038-1675572.

ISSN $0100-7203$.
Copyright (e 2019 by Thieme Revinter

Publicações Ltda, Rio de Janeiro, Brazil
License terms

(c) (1) 


\section{Palavras-chave \\ - parto domiciliar \\ - parto normal \\ - escala apgar}

somente dados de partos de baixo risco ocorridos em hospitais ou residências, incluindo tempo de gestação entre 37 e 41 semanas, gestação única, pelo menos quatro consultas de pré-natal, crianças com peso entre $2.500 \mathrm{~g}$ e $4.000 \mathrm{~g}$, e idade materna entre 20 anos e 40 anos e ausência de anomalias congênitas.

Resultados Em comparação ao nascido em ambiente hospitalar, o nascido em domicílio apresentou risco significativamente maior de pontuação 0 a 5 , tanto no primeiro minuto $(6,4 \%$ versus $3 \%$, razão de chance $[R C]=2,2$, intervalo de confiança [IC] $2-2,4)$ como no quinto minuto (4,8\% versus $0,4 \% ; R C=11,5 ; \mathrm{IC} 10,5-12,7)$. Outro achado que merece destaque é em relação às estimativas de recuperação quando de um Apgar inicialmente ruim ao primeiro minuto $(<6)$ para um subsequente melhor $(>$ 6) no quinto minuto. Neste cenário, os nascidos em domicílio apresentaram menor recuperação até o quinto minuto, persistindo em Apgar $<6$ na maior parte dos casos (71\% versus $10,7 \%$; OR 20,4; IC 17-24,6).

Conclusão Os resultados indicam piores escalas de Apgar para bebês nascidos em ambiente domiciliar, em comparação àqueles nascidos em ambiente hospitalar. Este é um estudo pioneiro e preliminar que atenta para as diferenças na escala de Apgar em relação ao local de nascimento domiciliar versus hospitalar no Brasil.

\section{Introduction}

Over the last decades, the number of births by cesarean section has been growing significantly in Brazil, which ranks the country among those carrying out this procedure the most in the world. ${ }^{1-3}$ On the other hand, an intense debate has been noticed in the search for the decrease of cesarean section births and the return to home births, which used to be the rule decades ago when the access to hospital health services was not an option.

Around the 1980s, non-governmental organizations and popular fronts started to give this cause a voice. Designations such as "obstetric violence" against "humanized birth" became popular, driven by growing reports of abuse from birth assistance in public and private hospitals. Those movements intend to recover the mother's autonomy and her main role in the process of giving birth. ${ }^{4,5}$

The year of 1993 was the milestone for the fight against the so called "obstetric violence," with the foundation of the Network for the Humanization of Labor and Birth (ReHuNa, in the Portuguese acronym), a non-profit organization that offers help reporting violence and embarrassing circumstances, which can turn the birth experience into one of "terror, anguish, helplessness, alienation and pain." ${ }^{6}$

In 2011, the United Nations (UN) Convention on the Elimination of All Forms of Discrimination against Women Committee sentenced the State of Brazil to pay compensation for the maternal death of a 28 -year-old woman deceased in 2002, victim of medical assistance negligence during gestation. ${ }^{7}$

The matter regained repercussion in March 2014, when attorneys representing a hospital filed a petition with the Court to interrupt a home birth. According to the report, the measure was justified because the parturient had undergone two previous cesarean sections and the fetus was in breech position. The woman refused to undergo cesarean section and left the hospital. The petition was successful, and the parturient was coerced to return. She then received manifestations of support from several national and international authorities, including the Federal Government's Office of Human Rights. ${ }^{8}$

Some of the most frequent reported reasons for choosing home births are: fewer interventions, sensation of being in control, a comfortable environment, and bad previous experiences in the hospital. ${ }^{9}$ The choice for home birth is also made when the mother does not agree with the recommendation of a cesarean section given in the hospital, such as in cases of breech, twin pregnancy and previous cesarean sections. ${ }^{10}$

The Health Secretary, through the "Rede Cegonha" program, ${ }^{11}$ requires from public governments the compliance of the World Health Organization's (WHO) 1996 document "Care in Normal Birth: A Practical Guide,"12 which includes the respect of mother's choice of birthplace among other recommended measures.

No study comparing neonatal results of home and hospital births was ever conducted in Brazil. Apgar scoring is a worldwide recognized system that remains to this day as an important neonatal prognosis tool as it was described 65 years ago. ${ }^{13}$ The purpose of this study is to promote informed choice for women and provide information on safety of place of birth (hospital births compared with home births) in Brazil based on 1 and 5-minute Apgar score distribution. Although the Apgar score alone does not predict long-term outcomes, its importance can be assured by the fact that infants scoring 0 to 3 in 5-minute Apgar score are related to increased mortality in the first week of life. ${ }^{14}$ This is a pioneer study conducted in Brazil whose results can be useful for future investigations and to help planning strategies on childbirth care. 


\section{Methods}

This study comprises population retrospective analysis based on live births records provided by the Informatics Department of the Unified Health System (DATASUS, in the Portuguese acronym) in cooperation with the Live Birth Information System (SINASC, in the Portuguese acronym). ${ }^{15}$ These are online public access data platform administered by Brazilian government that includes the records of births throughout Brazilian territory, collected from health care intuitions or notary offices (for home births). DATASUSSISNAC provides a rich source of data, mostly unexploited yet by the scientific community. Despite of some missing data, for example, individual data, still births and, in case of hospital births, if it was initially planned at home and then rushed to the hospital, this is the most complete source of information for births in Brazil.

Mother profile and Apgar score of naturally born infants (without forceps assistance) in Brazil, between 2011 and 2015, in both settings-home and hospital-were collected. To avoid possible bias among comparisons due to risk childbirth, a choice was made to include only deliveries considered to be of good prognosis, from low-risk pregnancies, including gestational time between 37 and 41 weeks, singleton pregnancy, with at least four visits of prenatal care, infants weighing between 2,500-4,000 g, mother age between $20-40$ years old, and absence of congenital anomalies. Schematic representation for methodology is presented in - Fig. $\mathbf{1}$.

Apgar scoring system was set as endpoint because of its worldwide recognition tool as an important neonatal prognosis marker, as described by Dr. Virginia Apgar in $1953 .{ }^{13}$ The scoring system ranges from zero to ten and corresponds to the summing up of the score obtained by the evaluation of five criteria: heart rate, respiration, muscle tone, reflex irritability and color. Distribution of newborns was obtained according to different 1-minute and 5- minute Apgar zones: 0-2, 3-5, 6-7, $8-10$. These zones are the usual presentation at the birth certificate. Thus, birth records without Apgar score were excluded. Three ratios were then obtained: 1 ) the proportion of newborns presenting with the bottom scores, $0-2$ and 3-5, in relation to birthplace, at the first minute; 2 ) the same, at the fifth minute; 3) newborns who, presenting low 1-minute scores, sustained 5-minute scores below 6, expressing poor recovery (it is unknown whether they did recover at 10,15 or 20 minutes, because this information is not usually provided at the birth certificate). Chi-square, OR (odds ratio), and Fisher exact tests were calculated with GraphPad Prism software, version 7 (GraphPad Software Inc., La Jolla, CA, USA) and were considered significant if $p<0.05$.

\section{Results}

The cohort included 24,300 newborns born at home, and 2,955,748 born at the hospital, as shown in - Table 1. Some characteristics were associated with a higher rate of home births: North region $(35 / 1,000)$; indigenous ethnicity $(201 /$ $1,000)$; no schooling $(75 / 1,000)$ or less than 4 years $(25 / 1,000)$.

1-minute Apgar: $62.7 \%$ of home births did not have 1 minute Apgar scores registered at the birth certificate, in contrast to $2.1 \%$ of hospital births. These cases were excluded. The newborns distribution according to different 1minute Apgar scores are shown in - Table 2. As noted, 6.4\% of newborns from home births and $3 \%$ from hospital births had 1-minute Apgar scores below 6; therefore, the chance of a low score was 2.2 times higher for home births [OR $=2.2$ (IC 2-2.4); $p<0.0001$ ].
Live Births Records

- Natural Deliveries

- Home or Hospital

- 2011-2015

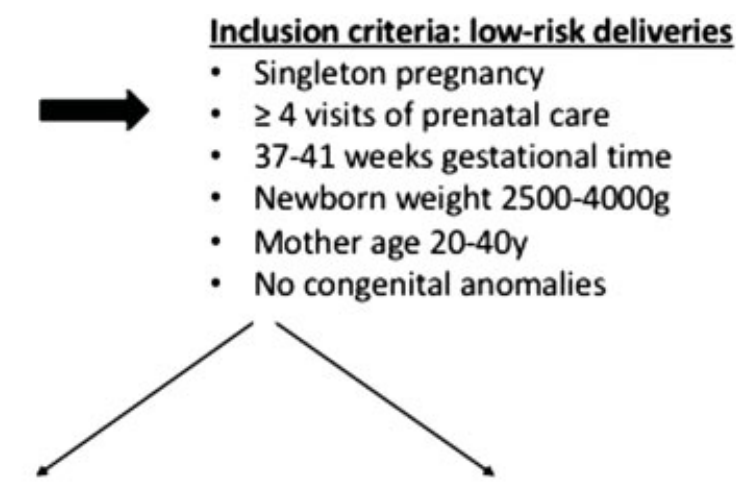

\section{HOSPITAL}

$\mathrm{N}=2.955 .748$

Exclusion criteria: Apgar unknown

1-minute

$\mathrm{N}=2.893 .357$

5-minute

$\mathrm{N}=\mathbf{2 . 8 9 4 . 9 7 5}$
Inclusion criteria: low-risk deliveries

- $\geq 4$ visits of prenatal care

- 37-41 weeks gestational time

- Newborn weight 2500-4000g

- Mother age 20-40y

No congenital anomalies

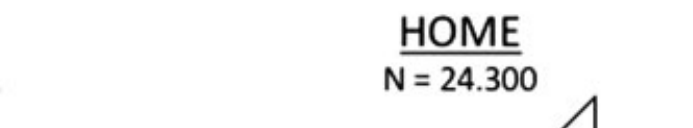

Fig. 1 Study design.

\author{
Hospital \\ - 1 -minute $\rightarrow 62.391(2,11 \%)$ \\ - 5-minute $\rightarrow 60.773(2,06 \%)$ \\ Home \\ - 1 -minute $\rightarrow 15.239$ (62,71\%) \\ - 5-minute $\rightarrow 15.221(62,64 \%$
}


Table 1 Characteristics of live birth population from natural birth, according to birthplace

\begin{tabular}{|c|c|c|}
\hline \multirow[t]{2}{*}{ Total } & Hospital & Home \\
\hline & $2,955,748$ (99.18\%) & $24,300(0.82 \%)$ \\
\hline \multicolumn{3}{|l|}{ Region } \\
\hline North & 294,545 (96.50\%) & $10,673(3.50 \%)$ \\
\hline Northeast & 846,091 (99.31\%) & $5,867(0.69 \%)$ \\
\hline Southeast & $1,207,120$ (99.58\%) & $5,097(0.42 \%)$ \\
\hline South & 400,799 (99.69\%) & $1,238(0.31 \%)$ \\
\hline Central-West & 207,193 (99.32\%) & $1,425(0.68 \%)$ \\
\hline \multicolumn{3}{|l|}{ Mother's age } \\
\hline $20-24$ years & 1,186,664 (99.29\%) & $8,443(0.71 \%)$ \\
\hline $25-29$ years & 925,778 (99.20\%) & $7,435(0.80 \%)$ \\
\hline $30-34$ years & 589,634 (99.04\%) & $5,691(0.96 \%)$ \\
\hline $35-39$ years & 253,672 (98.93\%) & $2,731(1.07 \%)$ \\
\hline \multicolumn{3}{|l|}{ Ethnicity } \\
\hline White & 968,838 (99.48\%) & $5,049(0.52 \%)$ \\
\hline Black & 168,745 (99.28\%) & $1,224(0.72 \%)$ \\
\hline Asian & 11,501 (99.16\%) & $97(0.84 \%)$ \\
\hline Mixed & 1,698,338 (99.27\%) & $12,441(0.73)$ \\
\hline Indigenous & 18,988 (79.36\%) & 4,938 (20.64\%) \\
\hline Ignored & 89,338 (99.39\%) & $551(0.61 \%)$ \\
\hline \multicolumn{3}{|l|}{ Marital status } \\
\hline Single & 1,296,900 (99.31\%) & 9,067 (0.69\%) \\
\hline Married & 849,893 (99.35\%) & $5,579(0.65 \%)$ \\
\hline Widowed & 5,683 (99.39\%) & $35(0.61 \%)$ \\
\hline Divorced & 28,366 (99.44\%) & $161(0.56 \%)$ \\
\hline $\begin{array}{l}\text { Consensual } \\
\text { union }\end{array}$ & 744,315 (98.80\%) & $9,009(1.20 \%)$ \\
\hline Ignored & $30,591(98.55 \%)$ & $449(1.45 \%)$ \\
\hline \multicolumn{3}{|l|}{ Schooling } \\
\hline None & $22,220(92.49 \%)$ & $1,803(7.51 \%)$ \\
\hline $1-3$ years & 139,994 (97.47\%) & $3,641(2.53 \%)$ \\
\hline $4-7$ years & $678,532(98.88 \%)$ & $7,710(1.12 \%)$ \\
\hline $8-11$ years & 1,783,070 (99.63\%) & $6,707(0.37 \%)$ \\
\hline$\geq 12$ years & 291,301 (98.78\%) & $3,611(1.22 \%)$ \\
\hline Ignored & $40,631(98.00 \%)$ & $828(1.20 \%)$ \\
\hline
\end{tabular}

5-minute Apgar: a high rate of uninformed Apgar on the records was also seen, $62.6 \%$ of home and $2.1 \%$ of hospital births. These cases were excluded for this analysis. The newborns distribution according to different 5-minute Apgar are shown in -Table 3. Apgar scores below 6 were seen in $4.8 \%$ of newborns at home, and $0.4 \%$ of newborns at the hospital. For 5-minute Apgar, the chance of a low score was 11.5 higher for home compared with hospital births (OR = 11.5[IC 10.5-12.7]; $p<0.0001)$.
Table 2 Distribution of newborns according to different 1-minute Apgar score by birthplace

\begin{tabular}{|l|l|l|l|l|}
\hline \multirow{2}{*}{ Birthplace } & \multicolumn{2}{|l|}{ Hospital } & \multicolumn{2}{l|}{ Home } \\
\cline { 2 - 5 } & $\mathbf{n}$ & $\%$ & $\mathbf{n}$ & $\%$ \\
\hline Apgar $<6$ & 86,179 & $2.98 \%$ & 577 & $6.37 \%$ \\
\hline $0-2$ & 16,325 & $0.56 \%$ & 418 & $4.61 \%$ \\
\hline $3-5$ & 69,854 & $2.41 \%$ & 159 & $1.75 \%$ \\
\hline Apgar $\geq 6$ & $2,807,178$ & $97.02 \%$ & 8,484 & $93.63 \%$ \\
\hline $6-7$ & 244,837 & $8.46 \%$ & 1,009 & $11.14 \%$ \\
\hline $8-10$ & $2,562,341$ & $88.56 \%$ & 7,475 & $82.50 \%$ \\
\hline Total & $2,893,357$ & $100 \%$ & 9,061 & $100 \%$ \\
\hline
\end{tabular}

Table 3 Distribution of newborns according to different 5-minute Apgar score by birthplace

\begin{tabular}{|l|l|l|l|l|}
\hline \multirow{2}{*}{ Birthplace } & \multicolumn{2}{|l|}{ Hospital } & \multicolumn{2}{l|}{ Home } \\
\cline { 2 - 5 } & $\mathbf{n}$ & $\%$ & $\mathbf{n}$ & $\%$ \\
\hline Apgar $<6$ & 12,718 & $0.44 \%$ & 439 & $4.84 \%$ \\
\hline $0-2$ & 4,526 & $0.16 \%$ & 387 & $4.26 \%$ \\
\hline $3-5$ & 8,192 & $0.28 \%$ & 52 & $0.57 \%$ \\
\hline Apgar $\geq 6$ & $2,882,257$ & $99.56 \%$ & 8,640 & $95.16 \%$ \\
\hline $6-7$ & 38,100 & $1.32 \%$ & 107 & $1.18 \%$ \\
\hline $8-10$ & $2,844,157$ & $98.24 \%$ & 8,533 & $93.99 \%$ \\
\hline Total & $2,894,975$ & $100 \%$ & 9,079 & $100 \%$ \\
\hline
\end{tabular}

Table 4 Persistence of Apgar < 6, from 1-minute to 5-minute, by birthplace

\begin{tabular}{|l|l|l|l|l|}
\hline \multirow{2}{*}{ Birthplace } & \multicolumn{2}{|l|}{ Hospital } & \multicolumn{2}{l|}{ Home } \\
\cline { 2 - 5 } & $\mathbf{n}$ & $\%$ & $\mathbf{n}$ & $\%$ \\
\hline Apgar $<6$ & 9,213 & $10.71 \%$ & 392 & $71.01 \%$ \\
\hline $0-2$ & 1,814 & $2.11 \%$ & 371 & $67.21 \%$ \\
\hline $3-5$ & 7,399 & $8.60 \%$ & 21 & $3.80 \%$ \\
\hline Apgar $\geq 6$ & 76,840 & $89.29 \%$ & 160 & $28.99 \%$ \\
\hline $6-7$ & 27,349 & $31.78 \%$ & 33 & $5.98 \%$ \\
\hline $8-10$ & 49,491 & $57.51 \%$ & 127 & $23.01 \%$ \\
\hline Total & 86,053 & $100 \%$ & 552 & $100 \%$ \\
\hline
\end{tabular}

Persistence of Apgar $<6$ from 1- to 5-minute: Persistence in low score means both 1-minute and 5-minute below 6 . Likewise, recovery was defined as a 5-minute Apgar above 6 succeeding a 1-minute Apgar below 6 . The analysis was not possible when 1-minute score was low, but the 5-minute score was not informed $(0.2 \%$ of hospitals and $4.3 \%$ of home records were excluded). The results are shown in - Table 4. The chance of a persistent low Apgar score was 20.4 times higher for home compared with hospital newborns (OR 
$=20.4$ [IC 17-24.6]; $p<0.0001$ ). When presenting a low 1 minute Apgar score, recovery to higher values was seen in almost $90 \%$ of the newborns at the hospital and only $29 \%$ of those at home.

Although 20\% of indigenous newborns were delivered at home, ethnicity was not accountable for the differences seen above. Among total indigenous newborns, 2.94\% had Apgar score below 6 , similar to the rate found for hospital deliveries. It is worth notice that the North region has one of the lowest ratios of newborns with low Apgar scores (2.13\%). Some characteristics were associated with higher ratios, including: Northeast Region (3.05\%), Southeast region (3.32\%); mother age $30-34$ years old $(3.06 \%)$, mother age $35-40$ years old (3.43\%); white (3.20\%), black (3.19\%) and Asian ethnicity (3.53\%); married (3.24\%); schooling $8-11$ years (3.06\%) and schooling $\geq 12$ years (3.60\%). More details about the distribution of newborns by Apgar score zone and mother profile can be seen in -Appendix 1 and 2.

\section{Discussion}

This study compared 1- and 5-minute Apgar scores of newborns from home births and from hospital births, as provided on births records in Brazil, between 2011 and 2015. In summary, the results show worse Apgar scores for babies born at home compared with those born at the hospital setting.

There were some surprising data. First, 63\% of home births did not have any Apgar score registered in the birth certificate, even though it has is a specific field for this information. It raises a few questions: Why no importance was given to the Apgar score? Were these babies unassisted? Or was it omitted for some reason? It seems more likely that there would be no reasons to omit a high score, but in fact it is not possible to demonstrate such conclusions.

A second surprising finding regards to persistently low scores until the fifth minute. Previous studies show that when both 1- and 5-minute scores are low (more specifically $<4$ ), there is increased risk of death and cerebral palsy. ${ }^{16}$ Our result showed that those born at home had poorer recovery when the score was low at the first minute, being persistently $<6$ until the fifth minute in most cases ( $71 \%$ versus $10.7 \%$, OR 20.4, IC 17-24.6). In other words, the chance of recovery until the fifth minute was only $29 \%$. In hospital births, on the other hand, recovery was seen in $89.3 \%$. Neonatal resuscitation maneuvers are a major factor accountable for this difference. This is expected data since neonatal resuscitation resources (such as aspiration cannula, oxygen, ventilation masks, intubation materials, and adrenaline) are readily available in hospitals. Still, the fact that a fast recovery was seen is less than a third of the infants born at home is worrisome.

It is important to remember that the population selected for analysis did not present high-risk factors for complications, such as: mother age under 20 or over 40 years old, preterm or post-term birth, prenatal care with less than four visits, birth weight under $2,500 \mathrm{~g}$ or over $4,000 \mathrm{~g}$, or congenital anomalies. It is quite likely that, if those conditions were included, the differences found between home and hospital births would be even greater. Such analysis was not made due to obvious bias to the detriment of home births.

The American College of Obstetricians and Gynecologists $(\mathrm{ACOG})^{17}$ and the American Academy of Pediatrics (AAP) ${ }^{18}$ state that hospitals and maternities are the safest places for natural birth, regardless of the pregnancy risks. Analysis of US births records have also shown poorer outcomes for home births, including higher risks of a null Apgar score (RR 10.5) and neurological dysfunction (RR 3.8). ${ }^{19}$

On the other hand, British entities, such as the Royal College of Obstetricians and Gynaecologists and the Royal College of Midwives, support natural home birth for low-risk pregnancies. $^{20} \mathrm{~A}$ meta-analysis sponsored by National Institute for Health found no differences between planned home and planned hospital births, regarding mortality, Apgar, neonatal jaundice, ICU transfer, conversion to cesarean section and puerperal hemorrhage. ${ }^{21}$ The method was "intention-totreat": the groups were not divided by birthplace, but according to where deliveries were planned to take place. In case of complications during home births, a fast transfer to hospital setting minimizes differences between the groups. It does not undermine the study, it is just not applicable to Brazil. Our lack of urban planning, and in some cases, of ambulances, often make rapid access to hospitals more difficult.

As a strong point of the present study, we highlight the population magnitude and the objectivity of data in birth certificates, which made the analysis less susceptible to mistakes in selection. For instance, in a referred Canadian study frequently used to accredit home births, parturients were checked in by the obstetric nurses hired to assist the delivery themselves. ${ }^{22}$ This kind of experimental design is not ideal, it is naturally biased on account of the nurses, who are knowledgeable of the objective of study and the hypothesis being tested. Dr. Virginia Apgar herself anticipated potential biases when she stated that "it is strongly advised that an observer, other than the person who delivers the infant, be the one to assign the score." 23 Those who deliver the infant are invariably emotionally involved with the births and the families, and thus cannot take an accurate decision on assigning the total score. In home births, it is common to have only one provider. The frequent high rate of Apgar $=10$ observed in home births is not reliable, more likely a sign of biased calculation. ${ }^{24}$

However, Apgar scores alone do not predict long-term outcomes and may not be an exact representation of birth conditions. There is also great interobserver variance: for the same newborn, two doctors may not give the same score in 18 to $45 \%$ of cases. ${ }^{25}$ An Australian study found that, regardless of the fact that live births Apgar scores had been equivalent, there were significant differences in stillborn rates, favoring hospital in comparison to home births. ${ }^{26}$ Thus, for future studies, we suggest follow-up throughout the first week, including data of intrapartum, neonatal, and infant deaths, and, if possible, follow-up of the first year as well, with attention to seizures and signs of neurological dysfunction.

According to our results, it is inferred that home births in Brazil may not establish equal safety in relation to hospital births, especially regarding neonatal resuscitation. Despite preliminary, and to encompass only 1- and 5-minute Apgar 
scores, they bring concerns about women, health care providers, and politic makers.

The Medical Board Council of São Paulo (CREMESP, in the Portuguese acronym) states that "childbirth care, including low-risk deliveries, should be done in the hospital setting." The same ordinance demands that "the physician that assists any home birth must report the occurrence."27

As previously mentioned, the reasons women frequently cited when choosing home birth are "fewer interventions, sensation of being in control and comfortable environment." This information can provide a few tracks. Hospitals should make efforts to improve the mother experience. They must have a full obstetric team that manages to pay attention to each parturient, especially when ob-gyns are busy performing surgeries and cesarean sections, including midwives and back-up physicians. It is mandatory that the hospital provides anesthesia services when required by the patient. Finally, cesarean sections without solid justifications must be avoided.

\section{Conclusion}

The present study found worse 1- and 5-minute Apgar scores for babies born at home, compared with those born at the hospital setting. When presenting 1 -minute score $<6$, home infants had poorer recovery, Apgar score was persistently $<6$ until the fifth minute in most cases (71\%). Although the Apgar score alone does not predict long-term outcomes, it remains to this day an important prognostic marker of neonatal death. This is a preliminary study that brings attention and concerns about the safety and training of professionals that conduct home births. It is certainly premature to speculate that home births are implied with higher mortality rates. However, it means the need of additional investigation to pursue if those lower Apgar scores are indeed related with long-term unfavorable outcomes.

\section{Contributors}

Bessa J. F. and Bonatto N. contributed with project and interpretation of data, writing of the article, critical review of the intellectual content and final approval of the version to be published.

\section{Conflicts of Interest}

None to declare.

\section{References}

1 Althabe F, Sosa C, Belizán JM, Gibbons L, Jacquerioz F, Bergel E. Cesarean section rates and maternal and neonatal mortality in low-, medium-, and high-income countries: an ecological study. Birth 2006;33(04):270-277 Doi: 10.1111/j.1523-536X.2006.00118.x

2 Betrán AP, Ye J, Moller AB, Zhang J, Gülmezoglu AM, Torloni MR. The increasing trend in caesarean section rates: global, regional and national estimates: 1990-2014. PLoS One 2016;11(02): e0148343 Doi: 10.1371/journal.pone.0148343

3 Torloni MR, Daher S, Betrán AP, et al. Portrayal of caesarean section in Brazilian women's magazines: 20 year review. BMJ 2011;342:d276 Doi: 10.1136/bmj.d276
4 Zanardo GLP, Uribe MC, Nadal AHR, Habigzang LF. Violência obstétrica no Brasil: uma revisão narrativa. Psicol Soc 2017;29: e155043 Doi: 10.1590/1807-0310/2017v29155043

5 Diniz CSG. Humanização da assistência ao parto no Brasil: os muitos sentidos de um movimento. Cien Saude Colet 2005; 10:627-637 Doi: 10.1590/S1413-81232005000300019

6 ReHuNa - Rede pela Humanização do Parto e Nascimento. http:// www.rehuna.org.br/index.php/quem-somos. Accessed March 15, 2018.

7 Senado Federal. Entenda o Caso Alyne. 2013https://www12.senado. leg.br/noticias/materias/2013/11/14/entenda-o-caso-alyne. Accessed March 15, 2018.

8 Secretaria de Direitos Humanos. Governo Manifesta Solidariedade a Adelir Carmem Lemos de Goes. 2014http://www.brasil.gov.br/ cidadania-e-justica/2014/04/governo-manifesta-solidariedade-a -adelir-carmem-lemos-de-goes. Accessed March 15, 2018.

9 Boucher D, Bennett C, McFarlin B, Freeze R. Staying home to give birth: why women in the United States choose home birth. J Midwifery Womens Health 2009;54(02):119-126Doi: 10.1016/j. jmwh.2008.09.006

10 Grünebaum A, McCullough LB, Brent RL, Arabin B, Levene MI, Chervenak FA. Perinatal risks of planned home births in the United States. Am J Obstet Gynecol 2015;212(03):350.e1-350. e6 Doi: 10.1016/j.ajog.2014.10.021

11 Ministério da Saúde. Portaria $N^{\circ} 1.459$, de 24 de junho de 2011. Institui, no âmbito do Sistema Único de Saúde - SUS - a Rede Cegonha. 2011http://bvsms.saude.gov.br/bvs/saudelegis/gm/2011/ prt1459_24_06_2011_comp.html. Accessed December 10, 2017.

12 Care in normal birth: a practical guide. Technical Working Group, World Health Organization. Birth 1997;24(02):121-123 Doi: 10.1111/j.1523-536X.1997.00121.pp.X

13 Apgar V. A proposal for a new method of evaluation of the newborn infant. Curr Res Anest Anal 1953;32(04):260-267

14 Casey BM, McIntire DD, Leveno KJ. The continuing value of the Apgar score for the assessment of newborn infants. N Engl J Med 2001;344(07):467-471 Doi: 10.1056/NEJM200102153440701

15 Ministério da Saúde. DATASUS. Nascidos Vivos.2016http://tabnet.datasus.gov.br/cgi/tabcgi.exe?sinasc/cnv/nvuf.def. Accessed December 10, 2017.

16 Moster D, Lie RT, Irgens LM, Bjerkedal T, Markestad T. The association of Apgar score with subsequent death and cerebral palsy: A population-based study in term infants. J Pediatr 2001; 138(06):798-803 Doi: 10.1067/mpd.2001.114694

17 ACOG Committee on Obstetric Practice. ACOG Committee Opinion No. 476: planned home birth. Obstet Gynecol 2011;117(2 Pt 1):425-428 Doi: 10.1097/AOG.0b013e31820eee20

18 Watterberg KL; Committee on Fetus and Newborn. Policy statement on planned home birth: upholding the best interests of children and families. Pediatrics 2013;132(05):924-926 Doi: 10.1542/peds.2013-0575

19 Grünebaum A, McCullough LB, Sapra KJ, et al. Apgar score of 0 at 5 minutes and neonatal seizures or serious neurologic dysfunction in relation to birth setting. Am J Obstet Gynecol 2013;209 (04):323.e1-323.e6 Doi: 10.1016/j.ajog.2013.06.025

20 Royal College of Obstetricians and Gynaecologists, Royal College of Midwives. Home Births. Apr 2007. Joint Statement 2. Published 2007. https://www.rcm.org.uk/sites/default/files/home_births_rcog_rcm0 607.pdf. Accessed December 10, 2017.

21 Olsen O, Clausen JA. Planned hospital birth versus planned home birth. Cochrane Database Syst Rev 2012;(09):CD000352 Doi: 10.1002/14651858.CD000352.pub2

22 Janssen PA, Lee SK, Ryan EM, et al. Outcomes of planned home births versus planned hospital births after regulation of midwifery in British Columbia. CMAJ 2002;166(03):315-323

23 Apgar V. The newborn (Apgar) scoring system. Reflections and advice. Pediatr Clin North Am 1966;13(03):645-650 Doi: 10.1016/S0031-3955(16)31874-0 
24 Grünebaum A, McCullough LB, Brent RL, Arabin B, Levene MI, Chervenak FA. Justified skepticism about Apgar scoring in out-ofhospital birth settings. J Perinat Med 2015;43(04):455-460 Doi: 10.1515/jpm-2014-0003

25 Kennare RM, Keirse MJNC, Tucker GR, Chan AC. Planned home and hospital births in South Australia, 1991-2006: differences in outcomes. Med J Aust 2010;192(02):76-80
26 Livingston J. Interrater reliability of the Apgar score in term and premature infants. Appl Nurs Res 1990;3(04):164-165 Doi: 10.1016/S0897-1897(05)80139-9

27 Conselho Regional de Medicina do Estado de São Paulo. Cremesp não recomenda realização de parto domiciliar. Jornal do Cremesp. Junho, 2011https://www.cremesp.org.br/?siteAcao=Jornal\&id= 1448. Accessed March 10, 2018.

Appendix 1 Newborn distribution by Apgar score zones, birthplace, and mother profile: first minute

\begin{tabular}{|c|c|c|c|c|c|c|c|c|}
\hline Score zones & $0-2$ & $3-5$ & $6-7$ & $8-10$ & Total & Apgar $<6(\%)$ & DP (MIN) & DP (MAX) \\
\hline \multicolumn{9}{|l|}{ Birthplace } \\
\hline Hospital & 16,325 & 69,854 & 244,837 & $2,562,341$ & $2,893,357$ & 2,978512503 & 3,00 & 2,96 \\
\hline Home & 418 & 159 & 1,009 & 7,475 & 9,061 & 6.37 & 6,89 & 5,88 \\
\hline \multicolumn{9}{|l|}{ Region } \\
\hline North & 1,222 & 5,015 & 31,052 & 255,767 & 293,056 & 2.13 & 2,18 & 2,08 \\
\hline Northeast & 4,268 & 20,368 & 84,996 & 699,416 & 809,048 & 3.05 & 3,08 & 3,01 \\
\hline Southeast & 7,860 & 31,722 & 85,391 & $1,068,795$ & $1,193,768$ & 3.32 & 3,35 & 3,28 \\
\hline South & 2,458 & 9,036 & 28,842 & 359,634 & 399,970 & 2.87 & 2,93 & 2,82 \\
\hline Central-West & 935 & 3,872 & 15,565 & 186,204 & 206,576 & 2.33 & 2,39 & 2,26 \\
\hline \multicolumn{9}{|l|}{ Mother's age (years) } \\
\hline $20-24$ & 6,228 & 27,522 & 101,832 & $1,027,136$ & $1,162,718$ & 2.90 & 2,93 & 2,87 \\
\hline $25-29$ & 5,159 & 21,497 & 75,590 & 806,489 & 908,735 & 2.93 & 2,97 & 2,90 \\
\hline $30-34$ & 3,546 & 14,236 & 47,743 & 515,317 & 580,842 & 3.06 & 3,11 & 3,02 \\
\hline $35-39$ & 1,810 & 6,758 & 20,681 & 220,874 & 250,123 & 3.43 & 3,50 & 3,35 \\
\hline \multicolumn{9}{|l|}{ Ethnicity } \\
\hline White & 6,079 & 24,773 & 73,893 & 858,056 & 962,801 & 3.20 & 3,24 & 3,17 \\
\hline Black & 1,047 & 4,217 & 13,257 & 146,493 & 165,014 & 3.19 & 3,28 & 3,11 \\
\hline Asian & 70 & 330 & 845 & 10,101 & 11,346 & 3.53 & 3,88 & 3,20 \\
\hline Mixed & 8,931 & 38,208 & 149,009 & $1,462,282$ & $1,658,430$ & 2.84 & 2,87 & 2,82 \\
\hline Indigenous & 118 & 459 & 1,801 & 17,243 & 19,621 & 2.94 & 3,19 & 2,71 \\
\hline Ignored & 498 & 2,026 & 7,041 & 75,641 & 85,206 & 2.96 & 3,08 & 2,85 \\
\hline \multicolumn{9}{|l|}{ Marital status } \\
\hline Single & 7,381 & 30,305 & 104,601 & $1,130,868$ & $1,273,155$ & 2.96 & 2,99 & 2,93 \\
\hline Married & 5,206 & 21,954 & 71,657 & 738,610 & 837,427 & 3.24 & 3,28 & 3,21 \\
\hline Widowed & 32 & 123 & 460 & 4,933 & 5,548 & 2.79 & 3,26 & 2,39 \\
\hline Divorced & 168 & 647 & 1,992 & 25,303 & 28,110 & 2.90 & 3,10 & 2,71 \\
\hline Consensual union & 3,809 & 16,252 & 64,218 & 645,189 & 729,468 & 2.75 & 2,79 & 2,71 \\
\hline Ignored & 147 & 732 & 2,918 & 24,913 & 28,710 & 3.06 & 3,27 & 2,87 \\
\hline \multicolumn{9}{|l|}{ Schooling (years) } \\
\hline None & 132 & 525 & 2,326 & 18,708 & 21,691 & 3.03 & 3,27 & 2,81 \\
\hline $1-3$ & 817 & 2,854 & 13,093 & 118,686 & 135,450 & 2.71 & 2,80 & 2,63 \\
\hline $4-7$ & 3,504 & 13,666 & 56,086 & 589,250 & 662,506 & 2.59 & 2,63 & 2,55 \\
\hline $8-11$ & 10,129 & 43,504 & 146,167 & $1,553,664$ & $1,753,464$ & 3.06 & 3,08 & 3,03 \\
\hline$\geq 12$ & 1,943 & 8,545 & 24,198 & 256,735 & 291,421 & 3.60 & 3,67 & 3,53 \\
\hline Ignored & 218 & 919 & 3,976 & 32,773 & 37,886 & 3.00 & 3,18 & 2,83 \\
\hline Total & 16,743 & 70,013 & 245,846 & $2,569,816$ & $2,902,418$ & 2.99 & 3,01 & 2,97 \\
\hline
\end{tabular}


Appendix 2 Newborn distribution by Apgar score zones, birthplace, and mother profile: fifth minute

\begin{tabular}{|c|c|c|c|c|c|c|c|c|}
\hline Score zones & $0-2$ & $3-5$ & $6-7$ & $8-10$ & Total & Apgar $<6$ (\%) & DP (MIN) & DP (MAX) \\
\hline \multicolumn{9}{|l|}{ Birthplace } \\
\hline Hospital & 4,526 & 8,192 & 38,100 & $2,844,157$ & $2,894,975$ & 0.44 & 0,45 & 0,43 \\
\hline Home & 387 & 52 & 107 & 8,533 & 9,079 & 4.84 & 5,30 & 4,41 \\
\hline \multicolumn{9}{|l|}{ Region } \\
\hline North & 537 & 703 & 3,550 & 287,972 & 292,762 & 0.42 & 0,45 & 0,40 \\
\hline Northeast & 1,611 & 2,741 & 13,546 & 790,872 & 808,770 & 0.54 & 0,55 & 0,52 \\
\hline Southeast & 2,070 & 3,324 & 14,459 & $1,175,852$ & $1,195,705$ & 0.45 & 0,46 & 0,44 \\
\hline South & 384 & 955 & 4,536 & 394,298 & 400,173 & 0.33 & 0,35 & 0,32 \\
\hline Central-West & 311 & 521 & 2,116 & 203,696 & 206,644 & 0.40 & 0,43 & 0,38 \\
\hline \multicolumn{9}{|l|}{ Mother's age (years) } \\
\hline $20-24$ & 1,865 & 3,131 & 15,171 & $1,142,907$ & $1,163,074$ & 0.43 & 0,44 & 0,42 \\
\hline $25-29$ & 1,597 & 2,475 & 11,767 & 893,421 & 909,260 & 0.45 & 0,46 & 0,43 \\
\hline $30-34$ & 982 & 1,744 & 7,709 & 570,877 & 581,312 & 0.47 & 0,49 & 0,45 \\
\hline $35-39$ & 469 & 894 & 3,560 & 245,485 & 250,408 & 0.54 & 0,57 & 0,52 \\
\hline \multicolumn{9}{|l|}{ Ethnicity } \\
\hline White & 1,264 & 2,691 & 11,980 & 947,550 & 963,485 & 0.41 & 0,42 & 0,40 \\
\hline Black & 328 & 479 & 2,250 & 162,225 & 165,282 & 0.49 & 0,52 & 0,46 \\
\hline Asian & 15 & 29 & 147 & 11,162 & 11,353 & 0.39 & 0,52 & 0,29 \\
\hline Mixed & 3,086 & 4,765 & 22,552 & $1,628,757$ & $1,659,160$ & 0.47 & 0,48 & 0,46 \\
\hline Indigenous & 73 & 45 & 200 & 19,285 & 19,603 & 0.6 & 0,72 & 0,50 \\
\hline Ignored & 147 & 235 & 1,078 & 83,711 & 85,171 & 0.45 & 0,50 & 0,41 \\
\hline \multicolumn{9}{|l|}{ Marital status } \\
\hline Single & 2,190 & 3,537 & 16,481 & $1,251,869$ & $1,274,077$ & 0.45 & 0,46 & 0,44 \\
\hline Married & 1,329 & 2,520 & 11,252 & 822,765 & 837,866 & 0.46 & 0,47 & 0,45 \\
\hline Widowed & 9 & 17 & 60 & 5,465 & 5,551 & 0.47 & 0,69 & 0,32 \\
\hline Divorced & 43 & 88 & 322 & 27,688 & 28,141 & 0.47 & 0,55 & 0,39 \\
\hline Consensual union & 1,272 & 1,992 & 9,646 & 716,836 & 729,746 & 0.45 & 0,46 & 0,43 \\
\hline Ignored & 70 & 90 & 446 & 28,067 & 28,673 & 0.56 & 0,65 & 0,48 \\
\hline \multicolumn{9}{|l|}{ Schooling (years) } \\
\hline None & 52 & 82 & 383 & 21,151 & 21,668 & 0.62 & 0,73 & 0,52 \\
\hline $1-3$ & 321 & 446 & 1,826 & 132,791 & 135,384 & 0.57 & 0,61 & 0,53 \\
\hline $4-7$ & 1,302 & 1,804 & 8,154 & 651,718 & 662,978 & 0.47 & 0,49 & 0,45 \\
\hline $8-11$ & 2,743 & 4,871 & 23,168 & $1,723,857$ & $1,754,639$ & 0.43 & 0,44 & 0,42 \\
\hline$\geq 12$ & 407 & 899 & 4,142 & 286,094 & 291,542 & 0.45 & 0,47 & 0,42 \\
\hline Ignored & 88 & 142 & 534 & 37,079 & 37,843 & 0.61 & 0,69 & 0,53 \\
\hline Total & 4,913 & 8,244 & 38,207 & $2,852,690$ & $2,904,054$ & 0.45 & 0,46 & 0,45 \\
\hline
\end{tabular}

